DOI: 10.34015/2523-4552.2020.3.14

УДК 343.8

Попельнюк Т. В., аспірант Східноєвропейського національного університету імені Лесі України

ORCID: 0000-0002-7399-6799

\title{
ПРО ДІАЛЕКТИЧНИЙ ВЗАЄМОЗВ'ЯЗОК І ВЗАЄМООБУМОВЛЕНІСТЬ СТРУКТУРНИХ ЕЛЕМЕНТІВ КРИМІНОЛОГІЧНОЇ ХАРАКТЕРИСТИКИ ЗЛОЧИНІВ, ЩО ВЧИНЯЮТЬСЯ У СФЕРІ ВИКОНАННЯ ПОКАРАНЬ УКРАЇНИ
}

У статті здійснено аналіз злочинів, що вчиняються засудженими до позбавлення волі та персоналом колоній у сфері виконання покарань, та доведено об'єктивний взаємозв'язок, взаємодію і взаємообумовленість зазначених суспільно небезпечних явищ, а також необхідність їх відображення у кримінологічній характеристиці.

Ключові слова: кримінологічна характеристика; злочин; персонал колоній; засуджений до позбавлення волі; сфера виконання покарань; запобігання; взаємозв'язок; взаємообумовленість; взаємодія.

В статье осуществлен анализ преступлений, совершенных осужденными к лишению свободы персоналом колоний в сфере исполнения наказаний, доказана объективная взаимосвязь, взаимодействие и взаимообусловленность этих общественно опасных явлений, а также необходимость их отражения в криминалистической характеристике.

ключевые слова: криминологическая характеристика; преступление; персонал колоний; осужденный $к$ лишению свободы; сфера исполнения наказаний; предупреждение; взаимосвязь; взаимообусловленность; взаимодействие.

Постановка проблеми. Як свідчить практика та результати спеціальних наукових досліджень [1], однією 3 ключових проблем сфери виконання покарань України упродовж 1991-2020 pp. $є$ злочинність. При цьому суб'єктами вчинення кримінальних правопорушень $\epsilon$ як засуджені, так і персонал органів та установ виконання покарань.

Саме на цьому аспекті зосереджена увага у Концепції реформування (розвитку) пенітенціарної системи України, схваленої розпорядження Кабінету Міністрів України у вересні 2017 року, пріоритетними завдання якої $\mathrm{y}$ зв'язку 3 цим має стати наукове обгрунтування якісних перетворень у сфері виконання покарань, у тому числі з питань запобігання злочинам.

Постановка завдання. Виходячи 3 цього, й була обрана тема цієї наукової статті та визначено їі 
головне завдання - встановити взаємозв'язок і взаємообумовленість вчинення злочинів 3 боку засуджених та персоналу органів i установ виконання покарань, 3 урахуванням цієї складової у змісті кримінологічної характеристики.

Аналіз останніх досліджень і публікацій. Результати вивчення наукової літератури свідчить про те, що в основному злочинність у сфері виконання покарань досліджувалась як предмет суспільно необхідної діяльності або засуджених [2], або персоналу Державної кримінальновиконавчої служби (ДКВС) України. Серед наукових праць у цьому сенсі можна виокремити розробки O. М. Бандурки, I. Г. Богатирьова В. В. Василевича, В. В. Голіни, Б. М. Головкіна, О. М. Джужи, Т. А. Денисової, О. Г. Колба, В. Я. Конопельського, I. М. Копотуна, А. В. Савченка, А. Х. Степанюка, В. М. Трубнікова, І. С. Яковець та інших учених. Поряд 3 цим, на доктринальному рівні не досліджені у повній мірі взаємозв'язок, взаємодія та взаємообумовленість між злочинами, що вчиняють у сфері виконання покарань засуджені та персонал ДКВС України, що й стало вирішальним при виборі теми цієї наукової статті та об'єктом розробки.

Виклад основного матеріалу. Згідно статистичних даних ДКВС України у період з 1991 року [3] по 2020 рік включно, у сфері виконання покарань було вчинено майже 10 тис злочинів (у середньому 350 щорічно) з боку засуджених, та більше 1 тис. 200 - з участю персоналу органів та установ виконання покарань (співвідношення 1:9). При цьому, об'єднуючими фоновими явищами, тобто негативними процесами, які взаємодіють із злочинністю та перебувають 3 нею у різного роду зв'язках та відносинах, $\epsilon$ вживання першими та другими суб'єктами кримінальних правопорушень спиртних напоїв, порушення правил обігу наркотичних речовин, їх аналогів та прекурсорів; налагодження позастатутних (не службових, заборонених тощо) взаємовідносин поміж собою; використання у ході відбування - виконання покарань інших заборонених предметів, а також допущення різноманітних дисциплінарних проступків, пов'язаних із сферою виконання покарань.

Як показали результати даного дослідження, досі у змісті кримінологічної характеристики злочинів, які вчиняються засудженими або персоналом органів та установ виконання покарань України, зазначені відомості майже не використовувались, що, без сумніву, негативно впливало на ефективність та результативність запобіжної діяльності у даній сфері суспільних відносин. При цьому, однією з умов, що сприяла такому положенню справ, стало відсутність єдності науковців як у визначенні змісту загального поняття «кримінологічної характеристики засуджених», так і зокрема, у змісті кримінологічної характеристики злочинів, що вчиняються у сфері виконання покарань.

У той самий час, як вірно зазначають окремі дослідники 3 означеної проблематики, кримінологічна характеристика відноситься на сьогодні до однієї 3 ключових доктринальних категорій, яка застосовується при аналізі будьякого злочину [5, с. 7-8]. Не 
залишаються у зв'язку 3 цим осторонь й науковці кримінальновиконавчого профілю, вивівши, зокрема, такі поняття, як: «кримінологічна характеристика злочинів, що вчиняються персоналом виправних колоній у ході виконання покарання у виді позбавлення волі» [6, с. 73]; «кримінологічна характерристика злочинів, що вчиняються персоналом Державної кримінальновиконавчої служби України у сфері виконання покарань; «кримінологгічна характеристика злісної непокори вимогам адміністрації установи виконання покарань» [7, c. 8] тощо.

Зазначені наукові розробки та інші праці 3 цих питань й стали методологічним підгрунтям при з'ясуванні змісту предмета дослідження даної наукової статті, враховуючи, що ні в підручниках, ні навчальних посібниках, ні в інших навчально-методичних виданнях по курсу «кримінологія» досі не в повній мірі з'ясовано сутність і зміст поняття «кримінологічна характерристика злочинів». При цьому, не дивлячись на деякі, як видається, недосконалості (спірні та дискусійні моменти тощо), що мають місце у сформульованих на доктринальному рівні понять кримінальної характеристики злочинів, які вчиняються у сфері виконання покарань, слід визнати їх теоретичне та практичне значення, зокрема, у контексті наукового обгрунтування системоутворюючих ознак даної правової категорії. Так, до таких у більшості випадків відносять:

1. Узагальнені офіційні відомості про злочини, що мають місце у сфері виконання покарань. При цьому, під узагальненням науковці розуміють порівняння окремих предметів, фактів, явищ тощо; виявлення спільних рис, особливостей й на їх основі здійснення висновків у формі загальних положень [8, с. 690].

у свою чергу, у правовій статистиці процес узагальнення статистичних даних про злочинність тощо називають зведенням i групуванням [9, с. 130], а під першим поняттям (завданням), розуміють процес упорядкування, систематизації i наукового оброблення первинного статистичного матеріалу для виявлення типових рис i закономірностей явищ та процесів, що вивчаються $[9$, с. 131], а під другим (групуванням) - розподіл множини одиниць сукупності на групи за певними, суттєвими для них ознаками, що досліджуються [9, c. 133].

Враховуючи, що сфера виконання покарань є характерною ознакою (як місце вчинення злочину) складів злочинів, які вчиняються як засудженими, так i персоналом ДКВС України, а також те, що статистичне групування - це один з основних методів оброблення та аналізу первинної статистичної інформації, що проявляється у розподілі сукупності на групи за істотними для даного дослідження ознаками [9, с. 134], варто визнати, що цей структурний елемент кримінологічної характеристики $\epsilon$ об'єднуючим для обох цих суб'єктів злочинів у зазначеній сфері суспільних відносин. Зокрема, до таких суспільних груп можна віднести злочини, що пов'язані 3 порушенням як засудженими, так i персоналом ДКВС України встановленого в законі порядку обігу 
наркотичних засобів, речовин, їх аналогів та прекурсорів. Так, у структурі пенітенціарної злочинності зазначені злочини у 2016 році склали $33 \quad \% \quad(101$ із 298 усіх зареєстрованих в УВП) [4, с. 2], а у злочинності персоналу ДКВС України - $45 \%$ [4, с. 13], що свідчить, крім цього, про діалектичний взаємозв'язок цих видів злочинів, а також їх взаємообумовленістю сферою виконання покарань. Суттєво не змінилась ситуація і у 2017-2020 роках.

2. Офіційні відомості про злочини, які вчиняються у сфері виконання покарань.

У тлумачних словниках слово «офіційно» означає витриманий відповідно до встановлених правил формальностей $[10$, с. 481]. На практиці офіційні відомості відображаються у відповідних статистичних матеріалах, звітах тощо. При цьому основним правовим джерелом офіційної статистики $\epsilon$ Закон України «Про державну статистику», в якому визначені форми статистичної звітності, включаючи й для органів та установ виконання покарань. Зазначені звіти включають у собі як відомості про пенітенціарну злочинність, так і про злочини, що вчинені персоналом ДКВС України, та складаються на підставі узагальнених даних, які містяться в Єдиному реєстрі досудових розслідувань (ст. 214 Кримінального процесуального кодексу (КПК) України) та інших облікових документах органів i установ виконання покарань $[9$, с. 75-109]. При цьому, загальними та, однозначно, об'єднуючими показниками даних двох груп злочинності $\epsilon$ відомості про спільну (ст. ст. 26-28 КК) злочинну діяльність засуджених i персоналу ДКВС України, яка, знову ж таки, $\epsilon$ результатом взаємодії, взаємообумовленості та впливу сфери виконання покарань на формування протиправної поведінки зазначених суб'єктів злочину.

3. Узагальнення відомостей про злочинність у сфері виконання покарань має здійснюватися за допомогою статистичних та інших наукових методів дослідження. Зокрема, у статистиці застосовуються такі методи: а) масового статистичного спостереження; б) групування; $\quad$ в) статистичного аналізу, зведеного та опрацьованого матеріалу; табличний і графічний; г) відносних величин; д) індексний; е) кореляційний $[9$, с. 15-16]. Крім цього, при узагальненні статистичних даних про злочини, які вчинили засуджені та персонал ДКВС України у сфері виконання покарань (i це теж є об'єднуючим елементом цих двох груп суб'єктів злочинів), застосовуються й загальнонаукові та спеціально-галузеві наукові методи дослідження [11, с. 620-646].

4. Узагальнені відомості мають містити у собі дані про стан, рівень, структуру, географію та топографію злочинів, які мали місце у сфері виконання покарань.

Саме останні показники (географія та топографія злочинів в органах та установах виконання покарань) й виступають об'єднуючим елементами пенітенціарної злочинності та злочинності персоналу ДКВС України. так, тільки у 2016 році 3 «географічної» точки зору найбільш криміногенно активними були УВП, що дислокувались у Донецькій, Вінницькій, Запорізькій 
та деяких інших областях [4, с. 7], а 3 огляду «топографії» - виправні колонії середнього рівня безпеки, у яких коефіцієнт злочинності на 1 тис. засуджених склав 5,53 випадки [4, с. 3] при 4,91 у середньому по всіх УВП $[4$, с. 6]. Аналогічні «географічні» та «топографічні» показники злочинності були характерними у 2016 році, для суб'єктів злочинів 3 числа персоналу органів та установ виконання покарань [4, с. 12-16], що виступає ще одним доказом їх взаємозв'язку та взаємообумовленості із пенітенціарною злочинністю. Практично незмінними зазначені показники залишаються і у 2017-2020 роках.

5. Відомості про детермінанти злочинів, що вчиняються у сфері виконання покарань.

У даному випадку об'єднуючими елементами пенітенціарної та злочинності персоналу ДКВС України $€: \quad$ а) детермінанти загальної злочинності в цілому в державі, які обумовлюють та сприяють формуванню протиправної поведінки як у засуджених, так і в персоналу органів та установ виконання покарань; б) детермінанти особливої (галузевої) злочинності (у даному випадку злочинність, що характерна для сфери виконання покарань, яка у тому числі детермінує вчинення злочинів як засудженими, так i персоналом ДКВС України); в) детермінанти специфічної злочинності (характерна для місць позбавлення волі або для покарань, не пов'язаних 3 ізоляцією особи від суспільства; г) детермінанти конкретного виду злочинів (злочину). При цьому, враховуючи, що, як слушно зауважив А. П. Закалюк, у найзагальнішому значенні цього поняття детермінація відображає діалектичну суттєву властивість реального буття загальний зв'язок, взаємозалежність та взаємообумовленість предметів, явищ i процесів, саме цей аспект кримінальної характеристики злочинів, що вчиняються у сфері виконання покарань, є об'єднуючими при оцінці протиправних діянь засуджених i персоналу ДКВС України.

6. Інформація про ціну злочинів, які вчиняються у сфері виконання покарань.

В кримінології під ціною злочинності розуміють кількісноякісний показник тієї шкоди і витрат суспільства, які $\epsilon$ наслідком її злочинних проявів. Виходячи 3 цього, слід визнати, що при вчиненні злочинів у ході відбування покарань (суб'єктами яких є засуджені) та їх виконання (суб'єкти - персонал органів та установ виконання покарань) об'єднуючими для цих двох груп злочинів $\epsilon$ об'єкти їх посягання (разовий - правосуддя та безпосередній - встановлений порядок виконання та відбування відповідного кримінального покарання), а, отже, й завдана для них шкода (пряма та непряма). При цьому, як при вчиненні злочинів засудженими, так і при реалізації протиправних намірів персоналом ДКВС України, завдається шкода i для інших супутніх об'єктів, зокрема авторитету державних органів (суду та виконання покарань, а також сфері виконання покарань в цілому).

Поряд з цим, варто зауважити, що питання про завдану шкоду відносяться до категорії оцінюючих. Як $з$ цього приводу вказано у п. 6 постанови Пленуму Верховного Суду України від 26 грудня 2003 року 
№ 15 «Про судову практику у справах про перевищення влади або службових повноважень», істотною, зокрема, є така шкода, яка полягає у порушення охоронюваних Конституцією чи іншими законами прав та свобод людини й громадянина, підрив авторитету та престижу органів державної влади, створення обставин та умов, що утруднюють виконання підприємствами, установами, організаціями своїх функцій тощо [12, с. 255-256].

Вчинення злочинів, як засудженими, так і персоналом ДКВС України саме й завдають шкоди охоронюваним правам юридичних і фізичних осіб, що також об'єднує по змісту посягань зазначені суб'єкти протиправної діяльності.

7. Важливими $\epsilon$ інші кримінологічно значущі ознаки, які варто враховувати у змісті кримінологічної характеристики злочинів, які вчиняються у сфері виконання покарань України (інформація про потерпілих від злочинів; дані про результативність запобіжної діяльності; відомості про особу злочинця, т. ін.). зокрема, як свідчить практика, i засуджені, i персонал ДКВС України об'єктами посягань обирають життя і здоров'я інших засуджених. Так, у 2016 році в УВП особи, які відбували покарання вчинили 3 умисні вбивства та 1 замах на вбивство, а також 2 тяжких і 2 середньої тяжкості тілесні ушкодження $[4$, с. 2]. У свою чергу, у 2016 році персоналом органів та установ виконання покарань у результаті перевищення службових повноважень нанесені тілесні ушкодження 7 засудженим [4, c. 13]. У 2017-2019 роках ситуація мало змінилась. В той же час у першому півріччі 2020 року вбивств або замахів на вбивство зафіксовано не було, разом з тим зареєстровано 3 випадки тяжких тілесних ушкоджень, 3 випадки групових членоушкоджень та 3 випадки групової непокори. Фактів незаконного застосування сили до засуджених протягом II кварталу 2020 не допущено [13].

Висновки. Таким чином, виходячи з отриманих у ході даного дослідження результатів, можна констатувати, що по змісту пенітенціарна злочинність та злочинність персоналу ДКВС України $\epsilon$ дві взаємозв'язані, взаємодіючі та взаємообумовлені інтегральні системи, об'єднуючими об'єктами протиправних посягань яких $\epsilon$ правосуддя, встановлений порядок виконання відбування покарання, життя та здоров'я особи та інші об'єкти життєдіяльності у сфері виконання покарань. Саме тому, при здійсненні кримінологічної характеристики злочинів, що вчиняються $\mathrm{y}$ зазначеній сфері суспільних відносин, слід враховувати у повній мірі інформацію про кожну окремо взяту інтегральну систему, що важливо 3 огляду підвищення їі практичної значущості та удосконалення правового механізму ефективності діяльності по запобіганню злочинам у сфері виконання покарань України.

\section{Список використаних джерел}

1. Колб О. Г. Забезпечення особистої безпеки засуджених у виправних колоніях України. Правова доктрина України : у 5 т. Харків: Право, 2013. Т. 5 : Кримінально- 
правові науки в Україні : стан, проблеми та шляхи розвитку / за заг. ред. В. Я. Тація, В. I. Борисова. С. 821-839.

2. Колб О. Г. Установа виконання покарань як суб’єкт запобігання злочинам : дис... докт. юрид. наук : 12.00.08. Київ: НАВС, 2007. 513 с.

3. Некоторые показатели деятельности учреждений уголовно-исполнительной системы МВД Украины в 1991 году : информ. бюллетень. Киев: ГУИН МВД Украины, 1992. $28 \mathrm{c}$.

4. Про стан правопорядку, ізоляції та нагляду, діяльність підрозділів охорони, пожежної безпеки та воєнізованих формувань Адміністрації Державної кримінальновиконавчої служби Міністерства юстиції. Київ: Адміністрація ДКВС України, 2020. 32 с.

5. Тарасов Н. В. Преступления, совершаемые сотрудниками милиции : криминологический аспект : автореф. дис. кан. юрид. наук : 12.00.08. Москва: Академия МВД РФ, 2000. 19 с.

6. Лопоха В. В. Запобігання злочинам, що вчиняються персоналом виправних колоній України : дис... кан. юрид. наук : 12.00.08. Київ: Інститут адвокатури України, 2016. 224 c.

7. Годлевська-Коновалова. В. Запобігання злісній непокорі вимогам адміністрації установи виконання покарань : автореф... дис. кан. юрид. наук : 12.00.08. Запоріжжя: Класичний приватний університет, 2019. 20 с.

8. Великий тлумачний словник української мови / упоряд. Т. В. Ковальова. Харків : Фоліо, 2005. 767 с.

9. Правова статистика : підручник / за заг. ред. проф. О. М. Джужи. Київ : Атіка, 2004. 448 c.

10. Великий тлумачний словник сучасної української мови / упоряд. 0. Є. Єрошенко. Донецьк : ТОВ «Глорія Трейд», 2012. 864 с.

11. Скакун А. Ф. Теорія держави і права : підручник : пер. з рос. Харків : Консум, 2001. $656 \mathrm{c}$.

12. Про судову практику у справах про перевищення влади або службових повноважень : постанова Пленуму Верховного Суду України від 26.12.2003 р. № 15 . Постанова Пленуму Верховного Суду України у кримінальних справах. / упоряд. В. В. Рожнова, А. С. Сизоненко, Л. Д. Удалова. Київ : ПАЛИВОДА А. В., 2011. С. 254-258.

13. Загальна характеристика Державної кримінально-виконавчої служби України: станом на 01 липня 2020 року. URL: https://kvs.gov.ua/wpcontent/uploads/2020/07/zagalna-harakterustuka.pdf (дата звернення: 03.09.2020).

\section{References}

Kolb, O. H. (2013). Zabezpechennia osobystoi bezpeky zasudzhenykh u vypravnykh koloniiakh Ukrainy. Pravova doktryna Ukrainy : u 5 t. Kharkiv: Pravo, T. 5: Kryminalno-pravovi nauky v Ukraini : stan, problemy ta shliakhy rozvytku / za zah. red. V. Ya. Tatsiia, V. I. Borysova, 821-839 [in Ukrainian].

Kolb, O. H. (2007). Ustanova vykonannia pokaran yak sub'iekt zapobihannia zlochynam (Dys... dokt. yuryd. nauk). Kyiv: NAVS [in Ukrainian].

Tarasov, N. V. (2000). Prestuplenyia, sovershaembe sotrudnykamy mylytsyy: krymynolohycheskyi aspekt. (Avtoref. dys. kan. yuryd nauk). Moskva: Akademyia MVD RF [in Russian].

Lopokha, V. V. (2016). Zapobihannia zlochynam, shcho vchyniaiutsia personalom vypravnykh kolonii Ukrainy. (Dys... kan. yuryd. nauk). Kyiv: Instytut advokatury Ukrainy [in Ukrainian].

Hodlevska-Konovalova, V. (2019). Zapobihannia zlisnii nepokori vymoham administratsii ustanovy vykonannia pokaran (Avtoref... dys. kan. yuryd. nauk). Zaporizhzhia: Klasychnyi pryvatnyi universytet [in Ukrainian]. 
T. Popelnyuk, Postgraduate student of the Eastern-Europe National University them Lesia Ukrainka

ORCID: 0000-0002-7399-6799

\section{About dialectical interconnection and interdependence structural elements of criminological characteristics crimes committed in the execution of punishment of Ukraine}

The article analyzes the crimes committed by prison staff sentenced to imprisonment in the field of penitentiary enforcement, proved the objective relationship, interaction and interdependence of these socially dangerous phenomena, as well as the need for their reflection in the forensic characteristics.

According to the practice and results of special scientific research, one of the key problems in the field of execution of sentences in Ukraine during 1991-2020 is crime. At the same time, the subjects of criminal offenses are both convicts and staff of penitentiary bodies and institutions.

This is the focus of the Concept of reforming (development) of the penitentiary system of Ukraine, approved by the order of the Cabinet of Ministers of Ukraine in September 2017, the priority of which in this regard should be a scientific basis for qualitative changes in the field of execution, including crime prevention issues.

Based on this, the topic of this scientific article was chosen and its main purpose was to establish the relationship and interdependence of crimes committed by convicts and staff of penitentiary bodies and institutions, taking into account this component in the content of criminal characteristics.

Keywords: criminological characteristics; the crime; colony personnel; sentenced to imprisonment; scope of punishment; a warning; interconnection; interdependence; interaction. 